Research Report

\title{
The Difference Of Antibacterial Power Between Cocoa Peel (Theobroma cacao L.) Extract $6,25 \%$ and Chlorhexidine $0,2 \%$ Againts Streptococcus sanguinis
}

\author{
Nila Murni Wulandari ,Edhie Arif Prasetyo ${ }^{2}$,Agus Subiwahjudi ${ }^{2}$, Tamara Yuanita ${ }^{2}$ \\ ${ }_{2}^{1}$ Undergraduate Student of Dental Medicine Faculty, Airlangga University, Surabaya - Indonesia \\ Staff Department of Conservative Dentistry, Dental Medicine Faculty, Airlangga Univeristy, Surabaya \\ - Indonesia
}

\begin{abstract}
Background: Streptococcus sanguinis is a bacterium that can cause failures in root canal treatments due its ability to penetrate the dentinal tubules to a depth of $400 \mu \mathrm{m}$ in just two weeks. Irrigation material is needed to stop the growth of this bacteria so that no bacteria can pass through by using chemicals, irrigation materials that are widely used such as Chlorhexidine 0,2\% but still lack because it cannot be used as a single irrigation solution because its effectiveness will be reduced if it is related to protein and organic dentine matrix and low Ph saliva.Therefore, research is needed to find natural ingredient that can be an alternative such as Cocoa peel extract was chosen because it contains active compounds, in the form of saponins, tanins, alkaloids, flavonoids, and terpenoids that have been known to have antibacterial properties a concentration of 6,25\% is used in accordance with the MKC of Streptococcus sanguinis. Aim: To compare the antibacterial power between cocoa peel extract (Theobroma cacao L.) 6,25\% and Chlorhexidine 0,2\% against Streptococcus sanguinis Method: This research is an experimental laboratory with a post-test only control group design. The diffusion method was used to determine the susceptibility of bacteria isolated from the material by planting the culture of Streptococcus sanguinis on the agar medium by swabbing the nutrient media which has been divided into 3 parts consisting of negative control, cocoa peel extract and Chlorhexidine, then each nurient media so that it is given a paper disk and $0.01 \mathrm{ml}$ liquid on each section. The diameter of the inhibition zone was observed after $2 \times 24$ hours using the calipers. Results: The average inhibitory zone that was formed using cocoa peel extract was 20,40 mm against Streptococcus sanguinis and Chlorhexidine was 18,36 against Streptococcus sanguinis. Conclusion: Cocoa peel extract (Theobroma cacao L.) 6,25\% had higher anti-bacterial power compared to 0,2\% Chlorhexidine against the growth of Streptococcus sanguinis.
\end{abstract}

Keywords: Cocoa peel extract 6,25\%, Streptococcus sanguinis, Chlorhexidine 0,2\%

Correspondence: Tamara Yuanita, Lecture Dental Medicine Faculty, Airlangga University, Surabaya Indonesia, +628155130747. tamara-yefkg.unair.ac.id

\section{BACKGROUND}

Root canal treatment is one of the treatments which is done by taking all the necrotic pulp tissue, forming tooth root canals to prevent recurrent infections. The purpose of root canal treatment is to maintain nonvital teeth in the arch to be able to survive as long as possible inside oral cavity by cleaning and disinfecting the root canal system thus reducing the appearance of bacteria. In conservative root canal treatment, the dentist performs the removal of necrotic pulp tissue, prepares the root canal system with irrigation and performs sterilization to prevent bacteria 1 .

Root canal treatment consists of three stages (Triad Endodontics), namely biomechanical preparation including cleansing and the sterilization including irrigation and disinfection and root canal filling. One of the important stages in 
cleaning and preparation (cleaning and shaping) is the stage of root canal irrigation. During the process of root canal preparation irrigation is carried out to clean the remaining pulp tissue, necrotic tissue

and dentine dust. Microorganisms remaining in the root canal or that grow after root canal obturation are the main cause of failure of root canal treatment. Therefore, elimination microorganisms with root canal irrigation are an important step in the success of endodontic therapy ${ }^{2}$.

The process of root canal failure was through a chemical reaction by bacteria, starting from the decease of soft tissue (pulp necrosis) then continues to the root canal. The most common bacteria in the necrosis root canal are anaerobic bacteria, besides that there are also microaerophilic, facultative anaerobes, and anaerobic obligate bacteria ${ }^{3}$. There are 2 species of bacteria that are usually dominates and causes failure of root canal treatment because of its ability to penetrate the dentinal tubules as deep as $400 \mu \mathrm{m}$ within two weeks, namely Enterococcus faecalis and Streptococcus sanguinis. Streptococcus sanguinis is a type of bacteria Streptococcs viridans are included in this type of alpha hemolytic bacteria shaped facultative gram-positive cocci. This species is the bacteria that first colonized the tooth surface and initiated the formation of dental plaque. ${ }^{4}$ A study of endocarditis in rabbits reported that Streptococcus sanguinis produced the glucosiltransferase enzyme that changes sucrose into glucan is a virulent factor and causes of sub-bacterial endocarditis. Streptococcus sanguinis can be found in the bloodstream and is able to form colonies in the heart valves. As a result of colonization of Streptococcus sanguinis in the heart valve and its presence in the blood circulation is septicemia and thrombosis which can cause death ${ }^{5}$. Considering the pathological properties of Streptococcus sanguinis bacteria, can even causes dangerous infectious diseases such as endocarditis, therefore, antibacterial agents are needed to overcome infections caused by these bacteria.

Chlorhexidine is an antiseptic which belongs to the class of bisbiguanide which is commonly used in the form of gluconate, chlorhexidine is bacteriostatic and bactericidal against microbes gram positive and gram negative. The antimicrobial effects of chlorhexidine are associated with

negative interactions between chlorhexidine (cation) and the surface of bacterial cells. After chlorhexidine is absorbed in the surface of the bacterial cell wall, chlorhexidine will reduce the resistance of cell membranes and cause intracellular material to be released.

One mechanism that can explain the effectiveness of chlorhexidine is the bond 
or interaction between the positive charge of chlorhexidine and the negative charge of phosphate particles in the bacterial wall, which allows penetration of the chlorhexidine molecule into the bacteria body and causes toxic effects. However, chlorhexidine cannot be used as a single irrigation solution for root canal treatment because it is unable to dissolve organic tissue and its effectiveness can be influenced by low $\mathrm{pH}$ saliva. ${ }^{6}$ It is actually encouraged to alternate the discovery of new antibacterial ingredient from natural materials.

In dentistry the use of herbal alternatives has been used for hundreds of years and has long been known for its high

antibacterial ability, analgesic, biocompatibility, anti-inflammatory and anti-oxidant. ${ }^{7}$ Indonesia is the third largest cocoa producer in the world, based on data from the Directorate General of Plantation, the total Indonesian cocoa production in 2010 was 900 thousand tons ${ }^{8}$. Cocoa pods contain alkaloids, flavonoids, tannins, saponins and terpenoids ${ }^{9}$. Various phytochemical components in these plants have several active compounds that have antibacterial properties that are known to inhibit pathogenic bacteria ${ }^{10}$. Cocoa peel extract can cause death cell by damaging cell membranes from bacteria, causing cell leakage and the release of intracellular compounds ${ }^{11}$. The alkaloid content can also causes bacterial death because it inhibits cell wall synthesis ${ }^{12}$. Tanin in cocoa peel extract can bind to teicoic acid which is an acid found in peptidoglycan which is part of the wall of gram-positive bacteria, this bond will facilitate inhibition of bacterial growth. Minimal inhibitory concentration (MIC) of the cocoa peel extract
(Theobroma cacao L.) against Streptococcus sanguinis are $3.125 \%$ and a minimal bactericidal concentration (MBC) cocoa peel extract (Theobroma cacao L.) against Streptococcus sanguinis is $6.25 \%$.

\section{MATERIAL AND METHODS}

a. How to sterilize Tools and Materials

The tools used in this study were sterilized in Autoclave (Oxoid, England) at a temperature of $121{ }^{\circ} \mathrm{C}$ for 30 minutes.

\section{b. Making Cocoa Peel Extract}

In this study researchers used cocoa peel extract with mature Forastero types or around 5.5-6 months old as many as $1 \mathrm{~kg}$ was obtained from Banyuwangi, cocoa skin is cleaned and then cut into thin until it reaches a thickness of about 1-2 mm. The peel of the cut cocoa fruit is dried in the open air for three days. After the cocoa peel is dry, then smooth it with a blender until it becomes a fine powder ${ }^{13}$. Then 100 grams of cocoa peel powder is macerated using a solvent by immersing $400 \mathrm{ml}$ of $70 \%$ ethanol and stirring several times, let stand for 24 hours in erlenmayer. Immersion is carried out at room temperature on the shacker at a speed of $120 \mathrm{rpm}$ for 24 hours. Then the results of the solution are filtered with Whatman filter paper No.40, so that it will be obtained maserate. Solvents (ethanol) in maserate were evaporated to free from ethanol solvent with rotary vacuum evaporator until pure extracts were obtained. The concentrated extract was taken $2 \mathrm{ml}$ then removed to a concentration of $6.25 \%$. 


\section{c. Dilution of Cocoa Peel Extract}

Dilution of cocoa peel extract was carried out at the Surabaya Industrial Research and Consultation Center. Making cocoa peel extract formulations with various concentrations using the dilution method of cacao peel extract with sterile aquades. Dilution is done by using the concentration and volume comparison formula as follows:

$$
\mathrm{M} 1 \times \mathrm{V} 1=\mathrm{M} 2 \times \mathrm{V} 2
$$

With M showing the concentration and $\mathrm{V}$ showing the volume, for both solutions with different concentrations.

\section{d. Preparation for Making Bacterial Culture}

The culture of Streptococcus sanguinis was taken from the stock of Streptococcus sanguinis using a sterile osse and planted on the Brain Heart Infusion Broth (BHIB) media. Then, it was incubated for 24 hours at $37^{\circ} \mathrm{C}$. The culture is matched with Mc Farland's standard, then thinned to reach the standard Mc. Farland 0.5 or equivalent to $1.5 \times 108 \mathrm{CFU} / \mathrm{ml}$. Equating the double blind turbidity of bacterial suspension (carried out by three people) is done by holding the test tube next to each other and looking at it on a white background with black stripes. If the turbidity of the bacterial suspension is still not the same, the bacterial suspension can be diluted or given additional bacteria.

After obtaining the same turbidity the standard, the standard suspension is diluted $^{14}$.
Prepare 9 petri dish containing nutrient so that each cup is divided into several parts (1 negative control group and 2 treatment groups). Taking culture of Streptococcus sanguinis bacteria from BHIB which has been synchronized with turbidity of Mc Farland 0.5 solution. Apply the culture to the entire surface of the nutrient to use a sterile cotton stick. Streptococcus sanguinis culture was planted on nutrient media to use cotton swabs with the swab method. Apply evenly to the surface of the agar. Drop the 6.25\% cocoa peel extract and $10 \mu \mathrm{l}$ chlorhexidine $0.2 \%$ on a paper disc. Apply the culture to the entire surface. Placing paper disc which have been extracted from

$6.25 \%$ cocoa peel extract and chlorhexidine $0.2 \%$ on each agar surface. Incubate for 24 hours in an incubator at $37^{0} \mathrm{C}$. Observation of inhibition zones, inhibition zones produced from each treatment have different

diameters and irregular shapes. Observations were made by measuring the longest diameter formed and the shortest diameter by using the calipers in millimeters $(\mathrm{mm})$ then adding up then divided by 2 so that the average was obtained.

e. Inoculation of Streptococcus sanguinis Bacteria in Nutrient Agar Media

Prepared 1 petri dish containing agar nutrient which was divided into several parts (1 negative control group and 2 treatment groups). Taking culture of Streptococcus sanguinis bacteria from BHIB which has been synchronized with turbidity of Mc Farland 0.5 solution. Apply the culture to the entire surface of the nutrient to use a sterile cotton stick. 


\section{f. Antibacterial test of $6.25 \%$ cocoa peel}

extract and chlorhexidine $0.2 \%$ against Streptococcus sanguinis bacteria

Streptococcus sanguinis was taken as much as 1 osse and then inserted into a tube containing BHIB media. Incubated for 24 hours in an anaerobic atmosphere in an anaerobic jar at $37^{\circ} \mathrm{C}$. Streptococcus sanguinis cultures grown on BHIB (Oxoid, England) are standardized according to $\mathrm{Mc}$ Farland 0.5. Petri dish containing nutrient to be divided into 3 parts is equal by marking the line using a marker on the back of the petri dish. Streptococcus sanguinis culture was planted on nutrient media to use cotton swabs with the swab method. Apply evenly to the surface of the agar. Drop the $6.25 \%$ cocoa peel extract and $0.01 \%$ chlorhexidine as much as the paper disk or disc paper. Place paper disks which have been extracted from $6.25 \%$ cocoa peel extract and $0.2 \%$ chlorhexidine on each agar surface. Incubate for 24 hours in an incubator (Biored, Japan) at $37^{\circ} \mathrm{C}$. Observation of inhibition zones, inhibition zones produced from each treatment have different diameters and irregular shapes. Observations were made by measuring the diameter formed around the well by using a sliding runway in units of millimeters (mm) and then divided by 2 so that the average was obtained.

\section{RESULT}

This study used the Streptococcus sanguinis bacteria obtained from Airlangga Surabaya Faculty of Dentistry Research Center. The bacteria were divided into three treatment groups, negative control groups with aqudes, group 1 with $6.25 \%$ cocoa pods extract and group 2 with chlorhexidine $0.2 \%$.
The results of the study are seen in Figure 1.

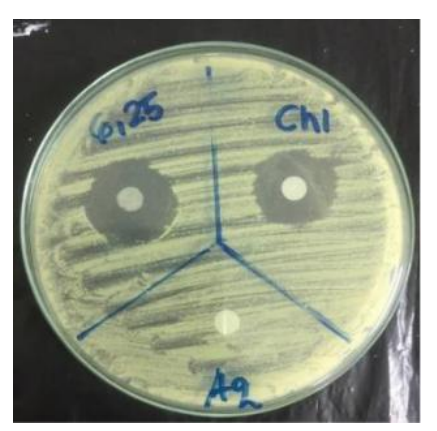

Figure 1. Results of differences in inhibition zones in cocoa peel extract $6.25 \%$, chlorhexidine $0.2 \%$ and Aquades as negative control .

Significant differences between treatment groups were calculated from the diameter of 9 samples, the average yield the average obtained in the group of $6.25 \%$ cocoa peel extract concentration was 20,400 $\pm 1,004$, while in the chlorhexidine group $0.2 \%$ was $18,362 \pm 0.706$. and the negative control does not indicate the diameter of the inhibitory zone formed.

\subsection{Analysis of Research Result}

Before the analysis test was carried out between groups the results of the study of $S$. sanguinis inhibitory zone diameters of $6.25 \%$ and chlorhexidine $0.2 \%$ cocoa peel extract were tested for normality of the data first in each group using the Saphiro Wilk Test to see normal distribution can be seen in table 1.

Table 1. Results of the Normality Test

\begin{tabular}{|c|c|c|c|}
\hline & $\begin{array}{c}\text { Negative } \\
\text { control }\end{array}$ & Group 1 & Group 2 \\
\hline Sig. & 0.000 & 0.357 & 0.122 \\
\hline
\end{tabular}


significance of each treatment group. If $\mathrm{p}$ $<0.05$, there is a significant difference. The test results show the value of $p=0$ (Table 3), so that the data has a significant difference.

Table 3. Kruskal-Wallis test results

\begin{tabular}{|l|c|}
\hline \multicolumn{1}{|c|}{ Group } & \multicolumn{1}{c|}{ Sig. } \\
\hline $\begin{array}{l}\text { Cocoa Peel } \\
\text { Extract }\end{array}$ & 0,000 \\
\hline $\begin{array}{l}\text { Chlorhexidine } \\
\text { 0,2\% }\end{array}$ & 0,000 \\
\hline $\begin{array}{l}\text { Negative control } \\
\text { (Aquadest) }\end{array}$ & 0,000 \\
\hline
\end{tabular}

Data can be said to be normal if the value of $p>0.05$ while from the above table $p$ value $<0.05$ in the negative control group means that the data obtained from research results are not normally distributed. Furthermore, the homogeneity test with Levene Test is carried out which if $p$ value> 0.05 means homogeneous data. Levene Test statistical test results in table 2.

Tabel 2.Results of the Homogeneity Test

\begin{tabular}{|c|c|}
\hline \multicolumn{2}{|c|}{ Levene's Test } \\
\hline p-value & 0.000 \\
\hline
\end{tabular}

Data can be said to be normal if the value of $p>0.05$ while from the above table $\mathrm{p}$ value $<0.05$ in the negative control group means that the data is abnormally distributed, so it uses a nonparametric test with kruskal-wallis. The kruskal-wallis test was conducted to determine the After conducting a significance test of the whole group, continued the difference test between one treatment group with the other treatment groups using the Bonfferoni Test. A value is considered to have a significant difference if the value of $p=<0.05$. The Bonfferoni Test test results obtained $p$ value $=0,000$ (table 4 ) which means that there are significant differences between treatment groups.
Table 4. Bonferroni Test test results

\begin{tabular}{|c|c|c|c|}
\hline Group & I & II & III \\
\hline I & - & - & - \\
\hline II & $0.000^{*}$ & - & - \\
\hline III & $0.000^{*}$ & $0.000^{*}$ & - \\
\hline
\end{tabular}

\section{DISCUSSION}

This research was carried out in vitro with the diffusion method, Streptococcus sanguinis bacteria obtained from the Airlangga Surabaya Faculty of Dentistry Research Center using 9 sample replications. Planting of Streptococcus sanguinis bacteria culture was carried out on agar media by swab on agar nutrient media which had been divided into 3 parts consisting of negative controls, $6.25 \%$ cocoa peel extract, and $0.2 \%$ chlorhexidine, then each nutrient.

The antibacterials used in this study were cocoa peel extract with a minimum concentration of killings on Streptococcus sanguinis bacteria which was $6.25 \%$, chlorhexidine $0.2 \%$ and aquades which were used as negative control groups. To determine the content contained in cocoa peel extract phytochemical tests were carried out. The results obtained from phytochemical tests were tannin $(6.11 \%)$, alkaloids $(5.06 \%)$, saponins $(4.05 \%)$, flavonoids $(3.91 \%)$, terpenoids $(2.94 \%)$, these results proved theory that states that cocoa peel extract contains antibacterial properties.

Each test material was dropped on a paper disk that was located on agar nutrient media and divided into 3 group zones, then a paper disk was diluted with a liquid of 0.01 $\mathrm{ml}$ of $6.25 \%$ cocoa peel extract and chlorhexidine $0.2 \%$ in each the ingredients, then incubated for $2 \times 24$ hours at $37^{\circ} \mathrm{C}$ in the anaerobic jar and then observed the inhibitory zone formed 
around the test material that had been dripped except in the negative control group because the result was no presence of inhibitory zone formation. This shows that $6.25 \%$ cocoa peel extract and $0.2 \%$ chlorhexidine have antibacterial properties against Streptococcus sanguinis bacteria. The results of this study showed the average inhibition zone for cocoa skin extract $6.25 \%$ for S.sanguinis at 20,400 $\mathrm{mm}$ and the average inhibition zone of chlorhexidine $0.2 \%$ for S.sanguinis at $18,362 \mathrm{~mm}$ and aquades as a negative control with a diameter of $0 \mathrm{~mm}$. Thus, $6.25 \%$ cocoa peel extract has a higher

antibacterial power than $0.2 \%$ chlorhexidine against S.sanguinis bacteria. This might happen because the content of compounds contained in cocoa peel extract works synergistically as antibacterial. The compound content of cocoa peel extract such as alkaloids of $5.06 \%$ has a working mechanism by inhibiting synthesis in the cell wall and causing lysis which can subsequently cause death cell ${ }^{15}$. Flavonoids $3.91 \%$ bind to proteins via hydrogen bonds so that the protein structure becomes damaged and disrupts the permeability of cell membranes resulting in bacterial death ${ }^{8}$. Terpenoids of $2.94 \%$ work by binding to porin (transmembrane protein) on the outer membrane of the cell wall bacteria that can create instability from bacterial cell membrane permeability, causing an imbalance of ions and bacterial cell wall metabolites causing nutrient deficiencies and the occurrence of cell necrosis and apoptosis which can cause death from bacterial cells ${ }^{5}$. Saponin $4.05 \%$ works by hydrolyzing the cell wall so that leaky cell walls and intracellular compounds come out resulting in bacterial death ${ }^{16}$. Tanin $6.11 \%$ can bind to teicoic acid, this bond will facilitate inhibition of bacterial growth $^{17}$.
The data from the Kruskal-Wallis Test and Bonfreroni Test statistical tests showed that the diameter of the inhibition zone between the $6.25 \%$ cocoa peel extract group and $0.2 \%$ chlorhexidine extract in this study had a significant difference. $6.25 \%$ cocoa peel extract may have a higher antibacterial power compared to $0.2 \%$ chlorhexidine against Streptococcus sanguinis bacteria.

\section{REFERENCES}

1. Habl C, Bodenwinkler A, Sturzlinger H. Endodontic treatment of molars, Stubenring: GMS Health Technology. 2006

2. Silveira, LFM, Silveira, CF, Martos, J and de Castro, LAS. Evaluation of the different irrigation regimens with sodium hypochlorite and EDTA in removing the smear layer during root canal preparation, Journal of Microscopy and Ultrastructure, 2013; 1(1), 51-6.

3. Baumgartner JG,Bakland L K, \& Sugita EL. Microbiology of endodontics and asepsis in endodontic practice, in Ingle, J.I., and Backland, L. K., (eds). Endodontics $5^{\text {th }}$ ed., London. BC Decke Inc; 2002.p. 67

4. Yamaguchi M,Terao Y,Ogawa T, Takashi T,Hamada S, Kawabata. S.Role of sortase A in bacterial colonization, Microbes infect; 2006.p. 2791-6.

5. Wink M, 2015, Modes of Action of Herbal Medicine and Plant Secondary Metabolites, Journal of Medicine; 2015. 2: 251-86.

6. Burton, Maxine, Cobb, Emma, and Schmidt. The effect of handwashing with water or soap on bacterial contamination of hand. Int.J.Environt. Res Public Health; 2011.p. 97.

7. Dubey S. Comparative antimicrobial efficacy of herbal alternatives (Emblica officinalis, Psidium guajava), MTAD, and $2.5 \%$ sodium hypochlorite against Enterococcus faecalis: An in vitro study, Indore; Elsevier; 2016.p. 45-8. 
8 Mulyatni AS, Budiani A, Taniwiryono D. Aktivitas antibakteri ekstrak kulit buah kakao (Theobroma cacao L.) terhadap Escherichia coli, Bacillus subtilis, dan Staphylococcus aureus, Bogor; Menara Perkebunan; 2012; 80(2): 77-84.

9. Kayaputri, I.L., Sumanti, D.M., Djali, M., Indiarto, R. \& Dewi, D.L. Kajian Fitokimia Ekstrak Kulit Biji Kakao (Theobroma cacao L.) Chimica et Natura Acta 2014; 2(1), 83-90.

10.Wendakoon, C., Calderon, P., \& Gagnon, D. Evaluation of selected medicinal plants extracted in different ethanol concentrations for antibacterial activity against human pathogens, Journal of Medicinally Active Plants 2012: 1(2): 60-8.

11.Ameliana Y, Herawati, Seno. Daya antibakteri penambahan propolis pada zinc oxide eugenol dan zinc oxide terhadap kuman campur gigi molar sulung non vital. Dental jurnal 2014; 47(4): 198-201.

12.Romas A, Rosyidah DU, Aziz MA. Uji Aktivitas Antibakteri Ekstrak Etanol Kulit Buah Manggis (Garcinia Mangostana L) Terhadap Bakteri Escherichia Coli Atcc 11229 Dan Staphylococcus Aureus Atcc 6538 Secara In Vitro, Surakarta; University Research Colloqium. 2015.

14.Delost,M.D. Introduction to Diagnostic Microbiology for the Labboratory Sciences,Jones \& Bartlett: University Youngstown Ohio; 2014p.120-1

15Lamothe RG, Michell G,Gattuso M, Diarra MS, Malouin F, Bouarab K.Plant Antimicrobial Agents and Their Effects on Plant and Human Pathogens, Quebec;Internasional.p.3400-19

16.Nuria Mc, Faizatun a, Sumantri. Uji aktivitas antibakteri ekstrak etanol daun jarak pagar (jatropha Curcas L) terhadap bakteri staphylococcus. Mediagro. Jurnal Ilmu-Ilmu Pertanian 2009;5(2): 26-37
17.Majidah D, Dwi WAF, Achmad G antibacterial Activity oc Celery Leaaves Extract (Apium Graveolens L.) against Streptococcus Mutans as an Alternative Mouthwash Jember: Universitas Jember.2014 
Conservative Dentistry Journal Vol.9 No.1 Januari-Juni 2019 : 40-47 